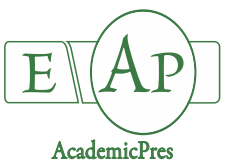

Basit A et al. (2020)

Notulae Botanicae Horti Agrobotanici Cluj-Napoca 48(2):705-715

DOI: $10.15835 /$ nbha48211901

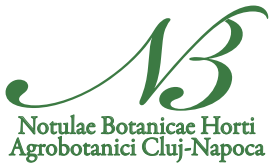

\title{
MAMP-triggered resistance induced by elicitor protein PeBA1 derived from Bacillus amyloliquefaciens NC6 in common bean (Phaseolus vulgaris L.) against green peach aphid (Myzus persicae Sulzer)
}

\author{
Abdul BASIT ${ }^{1,2 *}$, Talha NAZIR ${ }^{1}$, Abdul HANAN ${ }^{1}$, Muhammad Z. \\ MAJEED ${ }^{3}$, Muhammad FARHAN ${ }^{1}$, Dewen QIU $^{2}$, Yong WANG ${ }^{1 * *}$ \\ ${ }^{1}$ Guizhou University, Department of Plant Pathology, Agriculture College, Guiyang 550025, \\ China; malikbasituaf@gmail.com (*correspondingauthor);farhanuos35@outlook.com; \\ yongwangbis@aliyun.com (**corresponding author) \\ ${ }^{2}$ Chinese Academy of Agricultural Sciences, State Key Laboratory for Biology of Plant Disease and Insect Pests, Institute of Plant \\ Protection, Beijing 100081, China; talha23december@gmail.com; \\ bunnyus@gmail.com; qiudewen@caas.cn \\ ${ }^{3}$ University of Sargodha, Department of Entomology, College of Agriculture, Sargodha 40100, Pakistan; zeeshan.majeed@uos.edu.pk
}

\begin{abstract}
Bacterial microbe-associated molecular patterns (MAMPs) play an important role in innate plant immunity. This in vitro study evaluated the putative role of protein elicitor PeBA1 derived from Bacillus amyloliquefaciens NC6 strain in eliciting induced resistance type responses in common bean (Phaseolus vulgaris) plants against green peach aphid Myzus persicae. Nymphal developmental time of aphids was significantly prolonged and the fecundity was significantly reduced by different concentrations of PeBA1 elicitor (i.e. $40.51,24.91$ and $16.38 \mu \mathrm{g} \mathrm{mL}^{-1}$ ) applied at three different temperature regimes (i.e. 21, 27 and 30 ${ }^{\circ} \mathrm{C}$ ). Moreover, foliar application of PeBA1 elicitor protein strongly up-regulated the expression levels of salicylic acid (SA) pathway-associated genes, while the expression levels of jasmonic acid (JA) pathwayassociated genes exhibited a moderate induction. Quantification by LC/MSMS revealed a linear increase of both SA and JA plant defense hormones along with the time of exposure. Our findings suggest that the bacterial elicitor protein PeBA1 could be used as an effective biological pest management tool against phloem-feeding insect pests such as green peach aphids M. persicae.
\end{abstract}

Keywords: elicitor protein; jasmonic acid pathway; induced resistance; life-history traits; Myzus persicae; PeBA1; plant defense hormones; salicylic acid pathway

\section{Introduction}

In nature, plants are confronted by a wide range of pathogens and herbivore pests. In response to these biotic stresses, they have evolved different physiological and molecular defense mechanisms including hypersensitive response (HR), defense signaling pathways, reactive oxygen species (ROS) and reactive nitrogen 
species (RNS) synthesis (Delledonne et al., 2001; Garcia-Brugger et al., 2006). These plant defense pathways are regulated by transcriptional and metabolic changes through physiological reactions, and are often directly or indirectly activated by different signaling molecules such as nitric oxide (NO) and ROSs produced by the activation of plasma membrane proteins or protein phosphorylation (Garcia-Brugger et al., 2006).

Apart from plant-derived compounds, plant defense reactions are also elicited by a number of pathogenic microbe- or herbivore-derived molecular patterns (MAMPs or HAMPs) which ultimately induce systemic and local resistance against the pests (Durrant and Dong, 2004; Maffei et al., 2012). Various MAMP type elicitors have been extracted from different microorganisms such as fungi, bacteria and viruses and are usually glycoproteins, oligosaccharide, lipids and proteins (Boller and He, 2009; Ellis et al., 2009; Maffei et al., 2012). Most of these elicitor molecules are perceived by plants under attack as signal molecules to defend themselves through inducing resistance against attacking herbivore pests and/or pathogens via activation of different plant defense pathways (Bostock et al., 2001).

Plant hormones play a major role in triggering host plant defenses against different abiotic and biotic stresses such as cold, heat and drought stresses and herbivore infestation or pathogenic infection. For instance, salicylic acid (SA) and jasmonic acid (JA) are two most important signaling molecules that elicit and enhance various plant defense responses (Thaler $e$ t al., 2012). Commonly, SA has been found associated with resistance to biotrophic pathogens and herbivory by phloem-feeding insect pests, while JA is usually induced in plants stressed by necrotrophic pathogens and chewing insect pests (Glazebrook et al., 2005; Smith et al., 2009). Moreover, expression studies of classical JA- and JA-associated marker genes have shown the antagonistic biosynthesis and signaling of both these plant hormones (Mur et al., 2006; Loake and Grant, 2007).

Although, entomopathogenic fungi constitute an important biological control strategy against different insect pests (Vega et al., 2012), their ability to grow endophytically within different plant portions has suggested their new ecological functions (Quesada-Moraga et al., 2014; Nazir et al., 2019). For instance, these fungi may induce systemic resistance in plants against different biotic and abiotic stresses (Waller et al., 2005; SánchezRodríguez et al., 2018), suggesting their new perspective to develop novel plant protection strategies (SánchezRodríguez et al., 2016). Recently, a number of elicitor proteins have been isolated from different biotrophic and necrotrophic fungal species exhibiting induced resistance against herbivore pests and pathogens. For instance, the elicitor proteins $\mathrm{PeBC} 1$ and $\mathrm{PeBA} 1$ cloned respectively from a necrotrophic fungus Botrytis cinerea and bacterial strain Bacillus amyloliquefaciens NC6, induced resistance against diseases in Arabidopsis (Zhang et al., 2014) and in tobacco (Wang et al., 2016).

Keeping in view these novel ecological aspects of microbes, this in-vitro study was carried out to determine the biological activity of an elicitor protein PeBA1 derived from the gram-positive bacteria $B$. amyloliquefaciens NC6 strain against green peach aphids $M$.persicae. This elicitor protein consists of 285 amino acid residues and is capable of inducing systemic resistance features in tobacco plant including transcription of JA and SA related defense genes, cell death, HR necrosis and ROS synthesis (Wang et al., 2016). Moreover, as the abiotic factors such as temperature may influence the JA and SA signaling pathways (Zhu et al., 2010), bioassays were carried out at three different temperature regimes in order to assess the response of aphids to PeBA1 elicitor protein.

\section{Materials and Methods}

\section{Insect and plant culture}

In a growth chamber, a colony of green peach aphid $M$. persicae was maintained on common bean (Phaseolus vulgaris L.) plants in isolation cages. In order to ensure that aphids have been properly adapted to the chemistry of bean plants, they were maintained in a controlled chamber at 65 to $75 \%$ relative humidity and 
$21 \pm 2{ }^{\circ} \mathrm{C}$ temperature on the bean plants for at least three months prior to the start of actual bioassays. Bean plants were grown in plastic pots with sterile commercial potting mix and were raised in a greenhouse under natural light with day and night temperature fluctuating between 21 to $33^{\circ} \mathrm{C}$ (from June to September). Prior to experimentation, short-term feeding bioassays were conducted in order to observe the suitability of foliage from the control and elicitor-treated bean plants for aphid growth and development. Experimental bean plants were grown in $15 \mathrm{~cm}$ plastic pots filled with sterile commercial potting mix (manure and soil in 1:5 ratio). Ten days old plants at 3-leaf stage were used in bioassays.

\section{Protein purification}

The elicitor protein PeBA1 was extracted from the colony of bacterial strain Bacillus amyloliquefaciens NC6 cultured in $1 \mathrm{~L}$ of $\mathrm{LB}$ medium for $12 \mathrm{~h}$ at $16^{\circ} \mathrm{C}$ at $200 \mathrm{rpm}$. The pellets were then collected, broken and re-suspended by sonication. Then, centrifugation of the solution was performed for $15 \mathrm{~min}$ at $12000 \mathrm{rpm}$ followed by the collection and filtration of supernatant through a $0.22 \mu \mathrm{m}$ filter paper. Final purification of elicitor protein was carried out with help of affinity chromatography using a His-trap HP column and A, B, C and D loading buffers. Buffer A ( $50 \mathrm{mM}$ Tris- $\mathrm{HCl}, \mathrm{pH} 8.0)$ was used to wash the column, while buffer B (50 $\mathrm{mM}$ Tris- $\mathrm{HCl}, 200 \mathrm{mM} \mathrm{NaCl}$; $\mathrm{pH} 8.0$ ) was used to stabilize the column. Buffer C (50 mM Tris-HCl, 200 $\mathrm{mM} \mathrm{NaCl}$ and $20 \mathrm{mM}$ imidazole; $\mathrm{pH} 8.0$ ) and buffer D $(50 \mathrm{mM} \mathrm{Tris-HCl,} 200 \mathrm{mM} \mathrm{NaCl}$ and $500 \mathrm{mM}$ imidazole; $\mathrm{pH}$ 8.0) were used to elute the elicitor protein. Elicitor protein was then desalted by desalting tubes and by centrifugation at $4{ }^{\circ} \mathrm{C}$ at $5000 \mathrm{rpm}$. The molecular mass of purified recombinant elicitor protein was determined by $10 \%$ SDS PAGE gel and by using a protein marker.

\section{Bioassays with PeBAI elicitor protein against aphids}

Different concentrations of purified PeBA1 elicitor protein were bio-assayed against $M$. persicae aphids on bean plants. Treatments included three different concentrations of elicitor protein (i.e. 40.51, 24.90 and $\left.16.38 \mu \mathrm{g} \mathrm{mL}^{-1}\right)$ and the control in which plants were treated only with buffer A ( $50 \mathrm{mM}$ Tris- $\mathrm{HCl}, \mathrm{pH} 8.0$ ). Protein concentrations were determined by Bradford assay using bovine serum albumin (BSA) as standard. Elicitor treatments were applied on bean plants at 3-leaf stage with a precise spray bottle until the bean plants were thoroughly covered and began to drain. Three milliliters of each elicitor solution were applied on each plant. Control plants were sprayed with buffer only. Plants were allowed to dry overnight and next day five freshly molted (0-6 h old) adult winged aphids per leaf were released on these plants. Nymphal development time for each instar and total number of offspring produced by these F1 aphid progeny were recorded by consecutive observations at $3 \mathrm{~h}$ intervals until the completion of bioassays (in approximately 3 weeks). Each treatment was replicated 10 times and the bioassay was repeated thrice at three different temperature regimes (i.e. at 21,27 and $30^{\circ} \mathrm{C}$ ) independently.

\section{Isolation of RNA and cDNA synthesis}

For the molecular characterization of PeBA1 elicitor-induced resistance in plants against $M$. persicae aphids, bean plants were treated with the highest elicitor concentration (i.e. $40.51 \mu \mathrm{g} \mathrm{mL}^{-1}$ ), and were allowed to be infested by aphids as described in previous bioassay. Leaf samples were then collected from both treated and un-treated plants and RNA was extracted from these leaves using plant RNA kit Trans ER 301-01(All Style Gold Tech. Co. Ltd., Beijing, China) following manufacturer's protocol. Quantity and quality of the extracted RNA were measured with Nano Photometer (NP80-Touch, Implen Inc., NP West Burg, USA). Later on, this extracted RNA was reverse transcribed to cDNA using one step gDNA and cDNA kit Trans AT 341-01 (All Style Gold Tech. Co. Ltd., Beijing, China) following manufacturer's protocol. 


\section{$R T-q P C R$ analysis}

Using RT-qPCR, the relative expression of genes putatively involved in JA and SA plant defense pathways were determined in the elicitor-treated and buffer-treated bean plants. Marker genes involved in the JA pathway included phvul.001G000800g, phvul.001G001300g, phvul.001G017800g, phvul.002G175500g, phvul.002G06700g, phvul.003G011600g, phvul.003G111500g and phvul.003G096400g. Similarly, the SAassociated marker genes used in the study were phvul.006G048600g, phvul.008G272800g, phvul.008G057700g, phvul.009G022200g and phvul.011G176100g. Actin was used as the reference gene (internal control). Ten folds diluted cDNA was used as a template. Primer pairs used for the RT-qPCR amplifications of these genes are given in Table $S 1$. The efficacy and specificity of all primer pairs were validated through qPCR and gel electrophoresis. Thermocycler ABI 7500 (Applied Biosystems, USA) was used for RTqPCR amplifications. Each reaction mixture was $20 \mu \mathrm{L}$ holding $2 \mu \mathrm{L}$ of cDNA template, $0.5 \mu \mathrm{L}$ of each 10

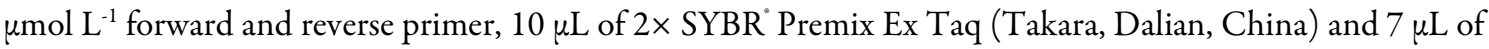
$\mathrm{ddH}_{2} \mathrm{O}$ ). PCR thermal program was constituted of preheating at $95^{\circ} \mathrm{C}$ for $30 \mathrm{~s}$, followed by 40 cycles of denaturation at $95^{\circ} \mathrm{C}$ for $30 \mathrm{~s}$ and annealing at $60^{\circ} \mathrm{C}$ for $40 \mathrm{~s}$ and elongation at $72{ }^{\circ} \mathrm{C}$ for $60 \mathrm{~s}$. There were three biological and three technical replicates for each sample.

\section{$L C-M S / M S$ analysis}

Apart from the expression analysis of potential JA- and SA-associated genes, we quantified these plant hormones in the leaves of aphid infested elicitor treated and buffer-treated plants using LC-MS/MS chromatography. For this determination, leaves of bean plants were collected at different time intervals (i.e. 6, 12,18 and $24 \mathrm{~h}$ ) and were frozen dried using liquid nitrogen. Leaf samples were then placed into $2 \mathrm{~mL}$ microcentrifuge tubes and were ground in a bead-beater using $2 \mathrm{~mm}$ tungsten-carbide beads with $25 \mathrm{~Hz} / \mathrm{s}$ for $4 \mathrm{~min}$. About $20 \mathrm{mg}$ of powdered tissue (equivalent to almost $200 \mathrm{mg}$ fresh weight) was extracted with $400 \mu \mathrm{L}$ of $10 \%$ methanol and $1 \%$ acetic acid. Extraction was repeated twice recovering about $90-95 \%$ of the sample. Both plant hormones were determined using QTRAP 5500 LC-MS/MS System (Applied Biosystems, Foster City, CA, USA) equipped with a 1290 Series HPLC System (Agilent Technologies, Foster City, CA, USA) and Turbo Ion Spray Electrospray Ionization (ESI) source. Quantifications were performed using multiple reactions monitoring (MRM) method in a negative ion detection mode ( $\mathrm{m} / \mathrm{z} 209.1 / 59.2$ for JA and 137.0/65.1 for SA). The retention times for JA and SA were 5.02 and $4.47 \mathrm{~min}$, respectively.

\section{Statistical analysis}

The experiments were repeated three times independently and the mean values of all parameters are presented in figures along with standard errors. Statistix Version 8.1 (Analytical Software, Tallahassee, FL, USA) was used for statistical analyses of data. Some data, for instance of fecundity of aphids, was subjected to square-root transformation prior to analysis. One-way analysis of variance was run to find out significant differences among treatment factors followed by Tukey's HSD test at $95 \%$ level of probability. The RT-qPCR expressions of genes were measured using comparative CT $\left(2^{-\Delta \Delta C T}\right)$ method. The fold change in the elicitortreated and buffer-treated (control) plant samples was compared by Student's $t$-test at $\alpha=0.05$.LC-MS/MS data acquisition and processing were carried out using $A B$ Sciex (V 1.6.2) software and were analyzed by regression analysis.

\section{Results}

\section{Influence of PeBAI elicitor on nymphal development time of aphids}

Analysis of variance showed a significant impact of different concentrations of PeBA1 elicitor protein $\left(\mathrm{F}_{3,468}=12.71 ; p<0.001\right)$, temperature regimes $\left(\mathrm{F}_{2,468}=274.27 ; p<0.001\right)$ and of their interaction $\left(\mathrm{F}_{6,468}=\right.$ $5.61 ; p<0.001$ ) on the overall developmental time of $M$. persicae (Table S2). The effect of protein elicitor on 
nymphal development time of aphids was found different at different temperature regimes. The developmental time of each nymphal instar was prolonged along with the concentration of PeBA1 elicitor. Maximum nymphal developmental time was recorded as 4.8 days for $1^{\text {st }}$ instar to 6.4 days for $3^{\text {rd }}$ instar nymphs for high concentration $\left(40.51 \mu \mathrm{g} \mathrm{mL}^{-1}\right)$ at low temperature $\left(21^{\circ} \mathrm{C}\right)$. While minimum nymphal development time (1.8 days) was recorded for $1^{\text {st }}$ instar for low elicitor concentration $\left(16.38 \mu \mathrm{g} \mathrm{mL}^{-1}\right)$ at high temperature regime (30 ${ }^{\circ} \mathrm{C}$ ). In buffer-treated (control) plants, the nymphal development time varied from maximum (4.2 days) for $3^{\text {rd }}$ instar at $21^{\circ} \mathrm{C}$ to minimum $\left(1.7\right.$ days) for $1^{\text {st }}$ instar at $30^{\circ} \mathrm{C}$ (Figure 1 ).

Overall, the effect of PeBA1 elicitor concentrations appeared to be highly significant for the $1^{\text {st }}$ instar $\left(\mathrm{F}_{3,108}=2.84 ; p=0.04\right), 2^{\text {nd }}$ instar $\left(\mathrm{F}_{3,108}=6.17 ; p<0.01\right), 3^{\text {rd }}$ instar $\left(\mathrm{F}_{3,108}=6.91 ; p=0.003\right)$ and $4^{\text {th }}$ instar $\left(\mathrm{F}_{3,}\right.$ $108=6.26 ; p<0.001)$. Nevertheless, the effect of PeBA1 elicitor on nymphal development time of all aphid instars was more significant at low temperature $\left(21^{\circ} \mathrm{C}\right)$ than at medium or high temperatures (Figure 1).

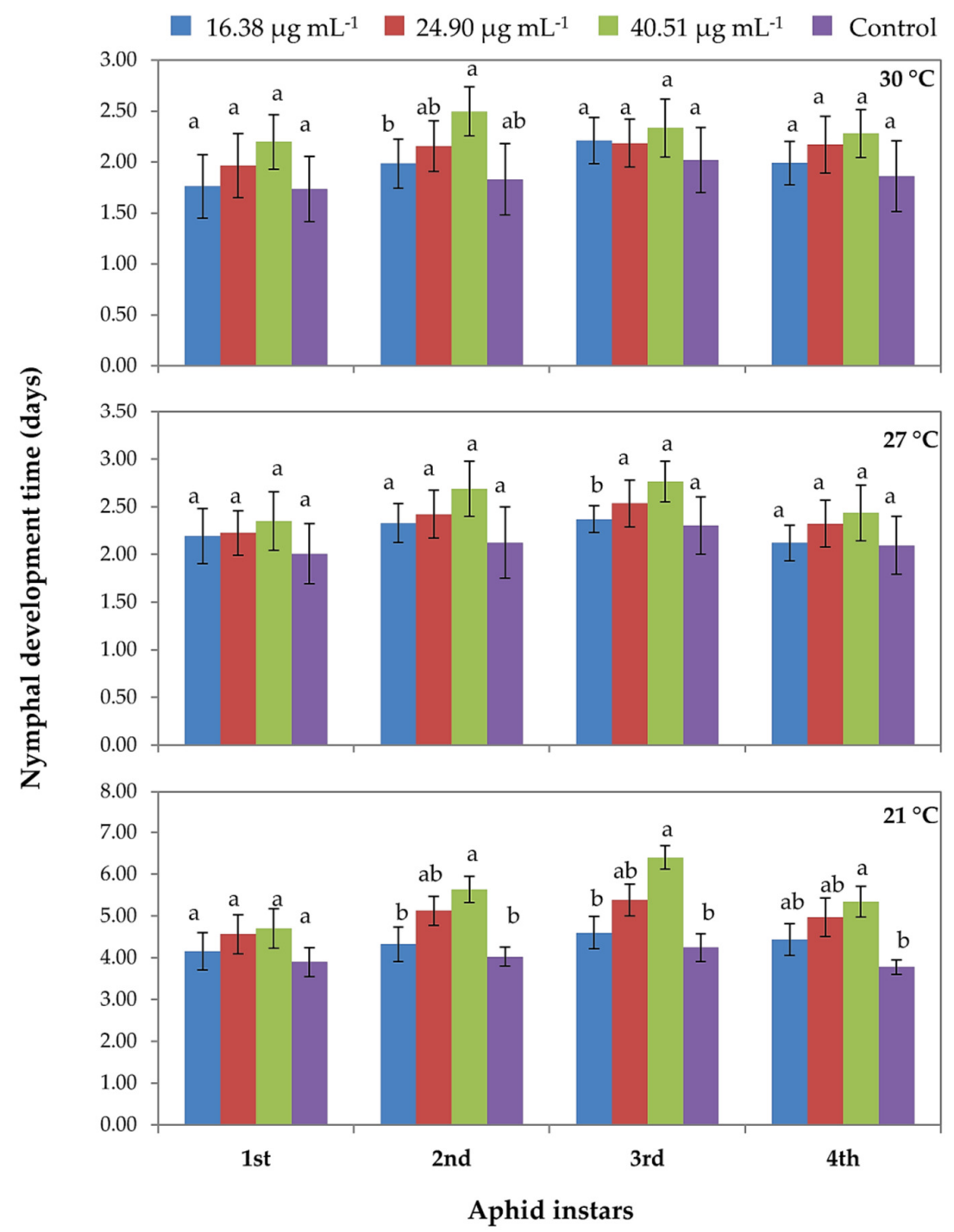

Figure 1. Mean development time ( \pm SE) of different nymphal instars of green peach aphid (Myzus persicae) on common bean plants in response to the application of PeBA1 elicitor protein at different temperature regimes $(n=10)$. For each temperature regime, different alphabets above bar tops indicate significant differences between treatments (one-way ANOVA; Tukey's HSD at $\alpha=0.05$ ) 


\section{Effect of Elicitor PeBAI on the fecundity of aphids}

Results showed that different concentrations of PeBA1 elicitor $\left(F_{3,108}=23.08 ; p \leq 0.001\right)$ and temperature regimes $\left(\mathrm{F}_{2,108}=225.72 ; p \leq 0.001\right)$ significantly influenced the fecundity of $M$. persicae adults (Table S3). Aphid individuals fed on the elicitor-treated plants produced significantly less number of offspring during their lifespan than those fed on the control (buffer-treated) plants. Moreover, minimum fecundity was observed at high temperature $\left(30^{\circ} \mathrm{C}\right)$, while the maximum fecundity was observed at low temperature $\left(21^{\circ} \mathrm{C}\right)$ (Figure 2).

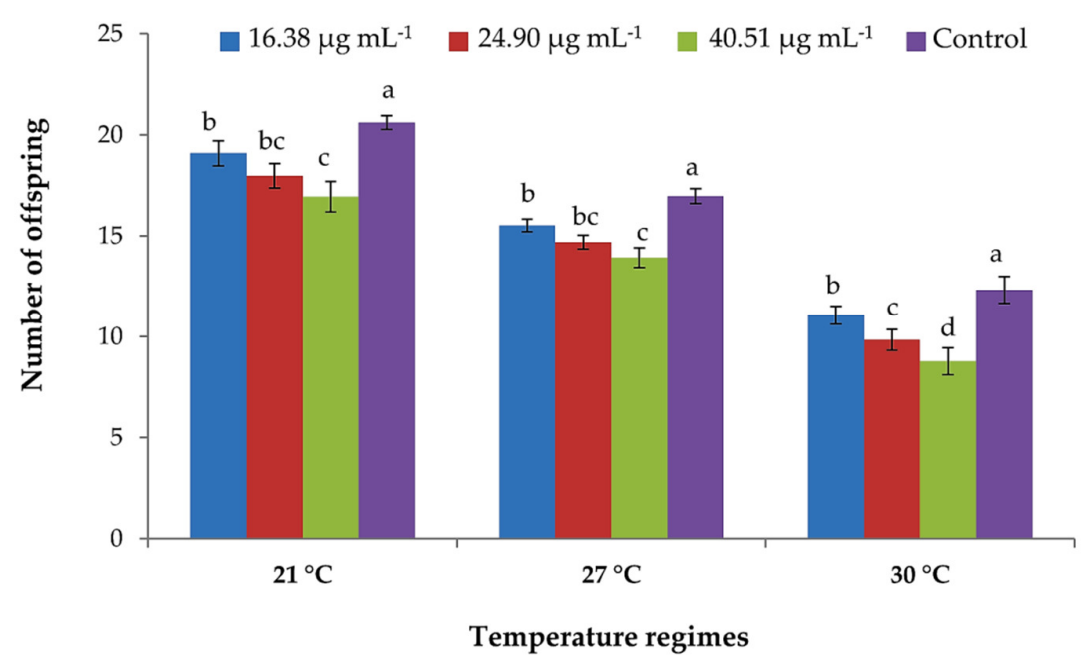

Figure 2. Mean fecundity ( \pm SE) of green peach aphids (Myzus persicae) on common bean plants in response to different concentrations of PeBA1 elicitor protein at different temperature regimes $(\mathrm{n}=10)$. For each temperature regime, different alphabets above bar tops indicate significant differences between treatments (one-way ANOVA; Tukey's HSD at $\alpha=0.05$ )

\section{Effect of PeBAI elicitor on expression of JA and SA pathway-associated genes}

Results revealed differential expression levels of different key genes associated with JA and SA pathways in elicitor-treated bean plants as compared to control ones. All SA-associated genes were highly up-regulated and were significantly different from the control samples for all observation times (Figure 3). Although relatively moderate but a similar trend of expression levels was observed for all JA-associated genes. Most of these genes were up-regulated at all observation times. However, one gene (phvul.002G175500g) initially showed no up-regulation till $6 \mathrm{~h}$ post aphid infestation and then was up-regulated from $12 \mathrm{~h}$ onward (Figure 4). Moreover, maximum gene expression levels for both types of key genes were recorded at 18 and $24 \mathrm{~h}$ of the elicitor application and aphid infestation.

\section{Quantification of JA and SA hormones}

Results of LC-MS/MS quantification of plant defense hormones have shown that levels of both JA and SA were gradually and significantly increased along with time. Maximum hormone amount was recorded after $24 \mathrm{~h}$ of elicitor treatment, while minimum was recorded at $6 \mathrm{~h}$. In control plants, no significant amount of JA was recorded, while a considerable quantity $\left(2.30 \mu \mathrm{g} \mathrm{g}^{-1}\right)$ of SA was observed in control plants (Figure 5). A positive correlation was found between these two plant hormones and time of exposure to protein elicitor PeBA1 $\left(\mathrm{R}^{2}=0.98\right.$ for SA and 0.82 for JA). 

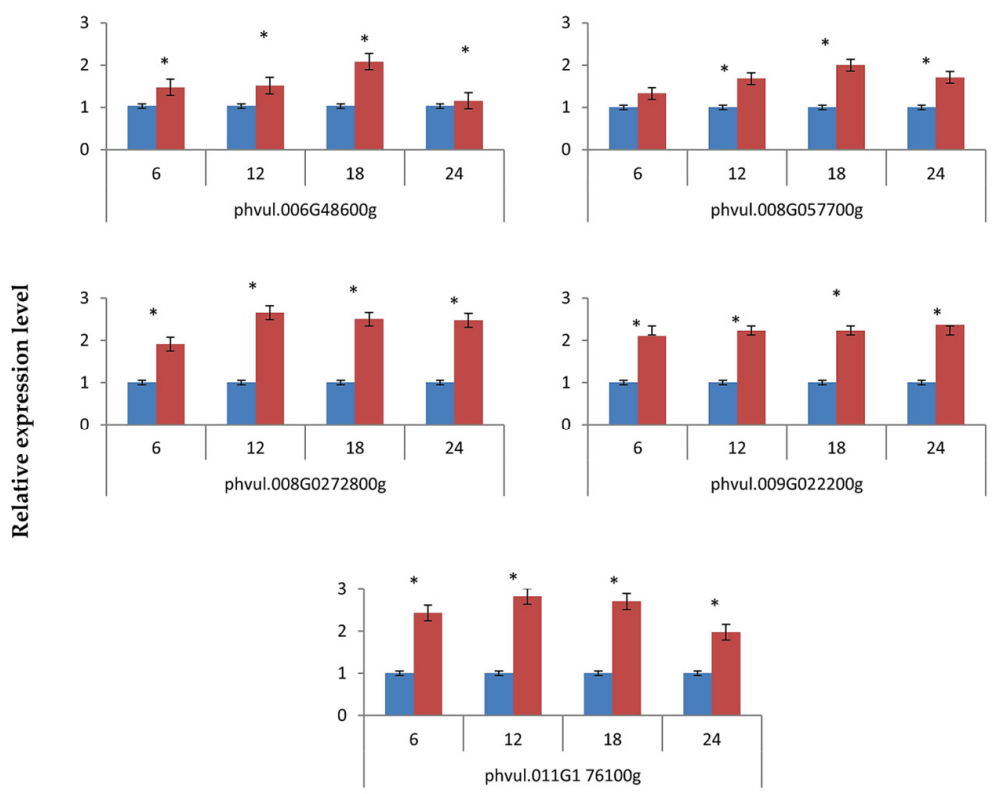

SA pathway-associated genes at different time intervals $(h)$

Figure 3. Relative expression levels ( \pm SE) of SA-associated plant defense pathway determined at different time intervals after the application of elicitor PeBA1 and aphid infestation. Red bars indicate the result of PeBA1 elicitor treatments, while blue bars show the result of buffer-treated (control) treatments. For each gene, asterisk symbols above bar tops indicate the significant difference among treatments (Student's t-test; $p<0.05$ )
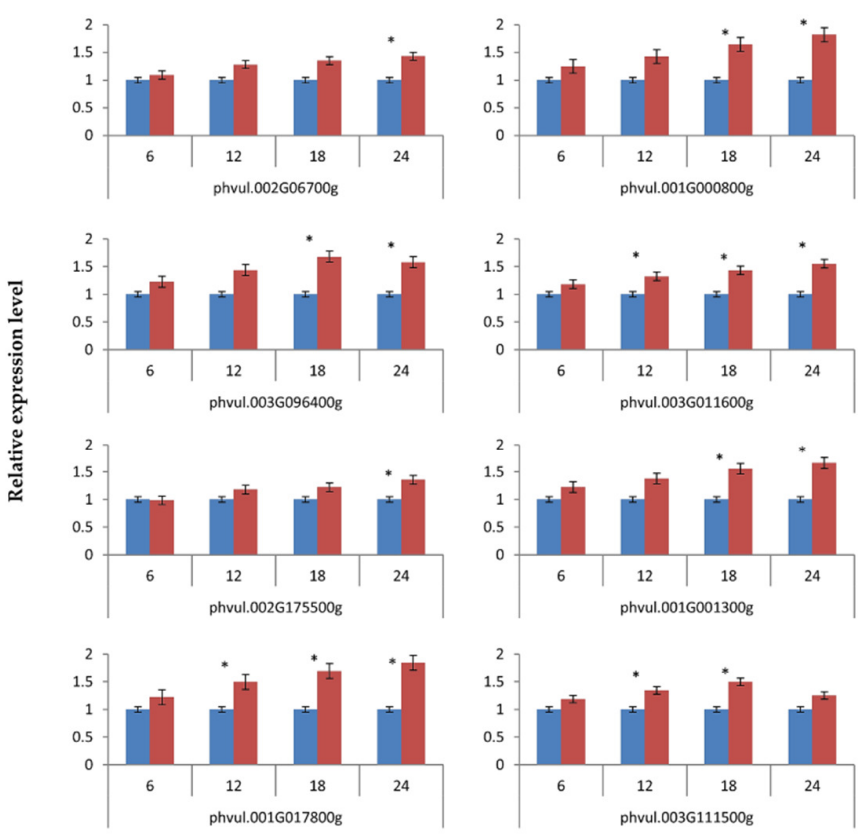

JA pathway-associated genes at different time intervals (h)

Figure 4. Relative expression levels $( \pm S E)$ of JA-associated plant defense pathway determined at different time intervals after the application of elicitor PeBA1 and aphid infestation. Red bars indicate the result of PeBA1 elicitor treatments, while blue bars show the result of buffer-treated (control) treatments. For each gene, asterisk symbols above bar tops indicate the significant difference among treatments (Student's t-test; $p<0.05$ ) 


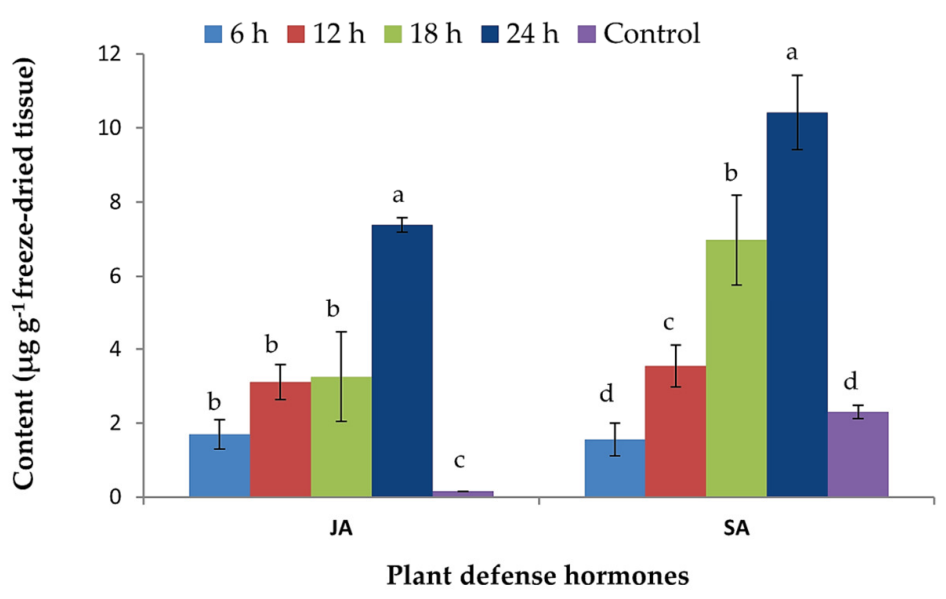

Figure 5. JA and SA plant hormone contents $( \pm$ SE) as determined by LC-MS/MS in one day old leaves of common bean (Phaseolus vulgaris) after the treatment of PeBA1 elicitor. For each plant hormone, different alphabets above bar tops indicate significant differences between time intervals (one-way ANOVA; Tukey's HSD at $\alpha=0.05$ )

\section{Discussion}

Elicitors play a vital role in signaling defense mechanisms in plants under attack and are considered as a novel biological pest management approach. Pathogenic fungi, either biotrophic or neurotropic, constitute a major source for microbes-derived elicitors such as PAMPs or MAMPs (Zhang et al., 2014; Wang et al., 2016). This in-vitro study elucidated the activity of an elicitor protein PeBA1 derived from B. amyloliquefaciens NC6 strain for the control of aphid M.persicae. The results of our bioassays have demonstrated that aphid population developed significantly slower on elicitor-treated plants than on the buffer-treated control plants. Our results are consistent with the previous studies demonstrating the negative impact of exogenous applications of different plant defense inducing chemicals including JA, benzothiadiazole (BTH) and methyl jasmonate (MJ) on the population growth and fitness parameters of different aphid species (Cooper and Goggin, 2005; Boughton et al., 2006). Similarly, our results corroborate the findings of Mallinger et al. (2011) who documented that methyl salicylate elicitor reduced the population of soybean aphid Aphis glycines up to $40 \%$. Similarly, some studies have shown that the activity of herbivore insect pests was significantly reduced after the application of plant defense inducing molecules such as MJ and BTH and other plant defense proteins such as proteinase inhibitors in tomato crop (Bostock et al., 2001; Bale et al., 2002). Exogenous application of elicitor molecules usually induce systemic or local resistance in plants against herbivore insect pests most probably by activating the plant SA and JA associated pathways resulting in the induction of different plant defense proteins such as peroxidase (POD), polyphenol oxidase (PPO), PR proteins, lipoxygenase and protein inhibitors etc.is well known (Bostock et al., 2001; Maffei et al., 2012).

Although PeBA1 elicitor application caused reduced nymphal developmental time and fecundity of aphids, the impact is statistically more significant and pronounced at low temperature $\left(21^{\circ} \mathrm{C}\right)$. Maximum nymphal development time was observed at lower temperature $\left(21^{\circ} \mathrm{C}\right)$ confirming the fact that with the increase of one degree in temperature, insect life cycle would become shorter (Bale et al., 2002). Similarly, the application of PeBA1 elicitor reduced the aphid fecundity. Aphids reproduced much lower on the elicitor treated plants as compared to buffer treated control plants. These results are in line with the previous studies 
evidencing a lower mean lifetime fecundity of aphids induced by the exogenous application of SA (Mahmoud and Mahfouz, 2015) and MJ (Boughton et al., 2006).

Our study revealed the potential of PeBA1 elicitor on the suppression of population performance and growth parameters of sap-feeding herbivores. However, as different chemical elicitors such as JA and MJ may induce the production of various proteinase inhibitors in plants as described in tomato plants (Farmer et al., 1992), more studies are needed to better comprehend the underlying mechanisms induced in bean plants by the PeBA1 elicitor protein which actually influenced the nymphal developmental time and fecundity of aphid individuals.

Moreover, SA and JA hormones play an essential role in signaling plant defense pathways and in the regulation of defense associated genes (Moran and Thompson, 2001; Thaler et al., 2012). These molecules enhance plant defense responses including resistance against insect herbivory and pathogenic attacks (Ali and Agrawal, 2012). In this study, we found that elicitor PeBA1 produced a significant and strong up-regulation of all key genes potentially associated with SA pathway, while a moderate up-regulation was observed in case of JA pathway associated genes. Our findings are in agreement with the fact that phloem-feeding insect pests such as aphids trigger more strongly the expression of SA pathway associated genes than those related to JA pathway (Smith et al., 2009; Ali and Agrawal, 2012; Coppola et al., 2013). This is further supported by the results of liquid chromatography-mass spectrometry which showed some quantity of SA contents in aphid infested control plants as compared to the negligible JA contents. This corroborates the fact that herbivory by sapfeeding pests such as aphids usually triggers more strongly the key genes associated with SA plant defense pathway rather than those involved in the JA pathway (Boughton et al., 2006; Coppola et al., 2013). Moreover, our results are in line with our recent study (Basit et al., 2019) which demonstrated a significant sub-lethal effect of $\mathrm{PeBC} 1$ protein elicitor, derived from the fungus Botrytis cinerea, on M. persicae concomitantly with a pronounced up-regulation of the expression level of genes related to SA and JA pathway.

\section{Conclusions}

In this study, we postulated that the application of PeBA1 elicitor would prolong the nymphal development time and reduce the fecundity of $M$. persicae on common bean plants. Bioassays performed with different concentrations of PeBAl applied at three different temperature regimes revealed that aphids developed and reproduced slower on elicitor-treated plants than on control plants. Furthermore, functional characterization of key genes potentially involved in JA and SA plant defense pathways indicated that elicitor PeBA1 induced a significant and differential expression of genes in bean plants concomitantly with an enhanced production of both hormones. Based on overall results of the study, it is concluded that MAMPs such as PeBA1 could be effectively used as novel biological pest control tool against aphids and other phloemfeeding insect pests.

\section{Acknowledgements}

This research was carried out in the State Key Laboratory for Biology of Plant Disease and Insect Pests, Institute of Plant Protection, Chinese Academy of Agricultural Sciences, Beijing, P.R. China. The authors are thankful to Prof. Dr. Sohail Ahmed and Kim Estenson for their valuable comments and proof reading of the manuscript. This study was financially supported by the National Key Research and Development of China (2017YFD0200900). 


\section{Conflict of Interests}

The authors declare that there are no conflicts of interest related to this article.

\section{References}

Ali JG, Agrawal AA (2012). Specialist versus generalist insect herbivores and plant defense. Trends in Plant Science 17(5):293-302.

Bale JS, Masters GJ, Hodkinson ID, Awmack C, Bezemer TM, Brown VK, Good JE (2002). Herbivory in global climate change research: direct effects of rising temperature on insect herbivores. Global Change Biology 8(1):1-16.

Basit A, Hanan A, Nazir T, Majeed MZ, Qiu D (2019). Molecular and functional characterization of elicitor PeBC1 extracted from Botrytis cinerea involved in the induction of resistance against green peach aphid (Myzus persicae) in common beans (Phaseolus vulgaris L.). Insects 10(2):35.

Bayat F, Mirlohi A, Khodambashi M (2009). Effects of endophytic fungi on some drought tolerance mechanisms of tall fescue in a hydroponics culture. Russian Journal of Plant Physiology 56(4):510-516.

Boller T, He SY (2009). Innate immunity in plants: an arms race between pattern recognition receptors in plants and effectors in microbial pathogens. Science 324(5928):742-744.

Bostock RM, Karban R, Thaler JS, Weyman PD, Gilchrist D (2001). Signal interactions in induced resistance to pathogens and insect herbivores. European Journal of Plant Pathology 107(1):103-111.

Boughton AJ, Hoover K, Felton GW (2006). Impact of chemical elicitor applications on greenhouse tomato plants and population growth of the green peach aphid, Myzus persicae. Entomologia Experimentalis et Applicata 120(3):175-188.

Cooper WR, Goggin FL (2005). Effects of jasmonate-induced defenses in tomato on the potato aphid, Macrosiphum euphorbiae. Entomologia Experimentalis et Applicata 115(1):107-115. doi: 10.1111/j.1570-7458.2005.00289.x

Coppola V, Coppola M, Rocco M, Digilio MC, D’Ambrosio C, Renzone G, Corrado G (2013). Transcriptomic and proteomic analysis of a compatible tomato-aphid interaction reveals a predominant salicylic acid-dependent plant response. BMC Genomics 14(1):515. doi: 10.1186/1471-2164-14-515

Delledonne M, Zeier J, Marocco A, Lamb C (2001). Signal interactions between nitric oxide and reactive oxygen intermediates in the plant hypersensitive disease resistance response. Proceedings of the National Academy of Sciences 98(23):13454-13459.

Durrant WE, Dong X (2004). Systemic acquired resistance. Annual Review of Phytopathology 42:185-209. doi: 10.1146/annurev.phyto.42.040803.140421

Ellis JG, Rafiqi M, Gan P, Chakrabarti A, Dodds PN (2009). Recent progress in discovery and functional analysis of effector proteins of fungal and oomycete plant pathogens. Current Opinion in Plant Biology 12(4):399-405.

Farmer EE, Johnson RR, Ryan CA (1992). Regulation of expression of proteinase inhibitor genes by methyl jasmonate and jasmonic acid. Plant Physiology 98(3):995-1002.

Garcia-Brugger A, Lamotte O, Vandelle E, Bourque S, Lecourieux D, Poinssot B, Pugin A (2006). Early signaling events induced by elicitors of plant defenses. Molecular Plant-Microbe Interactions 19(7):711-724.

Glazebrook J (2005). Contrasting mechanisms of defense against biotrophic and necrotrophic pathogens. Annual Review of Phytopathology 43:205-227.

Loake G, Grant M (2007). Salicylic acid in plant defence-the players and protagonists. Current Opinion in Plant Biology 10(5):466-72.

Maffei ME, Arimura GI, Mithöfer A (2012). Natural elicitors, effectors and modulators of plant responses. Natural Product Reports 29(11):1288-1303.

Mahmoud FM, Mahfouz HM (2015). Effects of salicylic acid elicitor against aphids on wheat and detection of infestation using infrared thermal imaging technique in Ismailia, Egypt. Pesticides and Phytomedicine 30(2):91-97.

Mallinger RE, Hogg DB, Gratton C (2011). Methyl salicylate attracts natural enemies and reduces populations of soybean aphids (Hemiptera: Aphididae) in soybean agroecosystems. Journal of Economic Entomology 104(1):115-124.

Moran PJ, Thompson GA (2001). Molecular responses to aphid feeding in Arabidopsis in relation to plant defense pathways. Plant Physiology 125(2):1074-1085. 
Mur LA, Kenton P, Atzorn R, Miersch O, Wasternack C (2006). The outcomes of concentration-specific interactions between salicylate and jasmonate signaling include synergy, antagonism, and oxidative stress leading to cell death. Plant Physiology 140(1):249-62.

Nazir T, Basit A, Hanan A, Majeed MZ, Qiu D (2019). In vitro pathogenicity of some entomopathogenic fungal strains against green peach aphid Myzus persicae (Homoptera: Aphididae). Agronomy 9(1):7.

Quesada-Moraga E, Herrero N, Zabalgogeazcoa Í (2014). Entomopathogenic and nematophagous fungal endophytes. In: Advances in Endophytic Research. Springer, New Delhi, India, pp 85-99.

Sánchez-Rodríguez AR, Barrón V, Del Campillo MC, Quesada-Moraga E (2016). The entomopathogenic fungus Metarhizium brunneum: a tool for alleviating Fe chlorosis. Plant and Soil 406(1-2):295-310.

Sánchez-Rodríguez AR, Raya-Díaz S, Zamarreño ÁM, García-Mina JM, del Campillo MC, Quesada-Moraga E (2018). An endophytic Beauveria bassiana strain increases spike production in bread and durum wheat plants and effectively controls cotton leafworm (Spodoptera littoralis) larvae. Biological Control 116:90-102.

Smith JL, De Moraes CM, Mescher MC (2009). Jasmonate-and salicylate-mediated plant defense responses to insect herbivores, pathogens and parasitic plants. Pest Management Science 65(5):497-503.

Thaler JS, Humphrey PT, Whiteman NK (2012). Evolution of jasmonate and salicylate signal crosstalk. Trends in Plant Science 17(5):260-270.

Vega FE, Meyling NY, Luangsa-ard J, Blackwell M (2012). Fungal entomopathogens, $2^{\text {nd }}$ Edition. In: Vega F, Kaya HE (Eds). Insect Pathology, Academic Press: San Diego, USA, pp 171-220.

Waller F, Achatz B, Baltruschat H, Fodor J, Becker K, Fischer M, ... Kogel KH (2005). The endophytic fungus Piriformospora indica reprograms barley to salt-stress tolerance, disease resistance, and higher yield. Proceedings of the National Academy of Sciences 102(38):13386-13391.

Wang N, Liu M, Guo L, Yang X, Qiu D (2016). A novel protein elicitor (PeBA1) from Bacillus amyloliquefaciens NC6 induces systemic resistance in tobacco. International Journal of Biological Sciences 12(6):757.

Zhang Y, Yang X, Zeng H, Guo L, Yuan J, Qiu D, (2014). Fungal elicitor protein PebC1 from Botrytis cinerea improves disease resistance in Arabidopsis thaliana. Biotechnology Letters 36(5):1069-1078.

Zhu Y, Qian W, Hua J (2010). Temperature modulates plant defense responses through NB-LRR proteins. PLoS Pathology 6(4):e1000844. https://doi.org/10.1371/journal.ppat.1000844
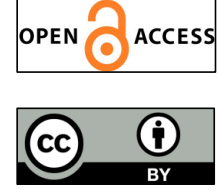

The journal offers free, immediate, and unrestricted access to peer-reviewed research and scholarly work. Users are allowed to read, download, copy, distribute, print, search, or link to the full texts of the articles, or use them for any other lawful purpose, without asking prior permission from the publisher or the author.

License - Articles published in Notulae Botanicae Horti Agrobotanici Cluj-Napoca are Open-Access, distributed under the terms and conditions of the Creative Commons Attribution (CC BY 4.0) License. (C) Articles by the authors; UASVM, Cluj-Napoca, Romania. The journal allows the author(s) to hold the copyright/to retain publishing rights without restriction. 
Supplementary Tables

TableS1. Primer pairs of keygenes potentially involved in the plant defense JA and SA pathways

\begin{tabular}{|c|c|c|}
\hline Target Gene & Forward Sequence $\left(5^{\prime} \rightarrow 3^{\prime}\right)$ & Reverse Sequence $\left(5^{\prime} \rightarrow 3^{\prime}\right)$ \\
\hline PHAVU_002G175500g & GAAAAGCGTGGAAAGCTACG & AGCCATGAACGATGATCTCC \\
\hline PHAVU_001G017800g & GGGAGAAGCTGCTGAAACAC & CCGACCTGAATATCGAAGGA \\
\hline PHAVU_003G111500g & GAATTTCCCTGCTGCTCTTG & CTGGCTTAGCCTCAGGAATG \\
\hline PHAVU_001G000800g & AGCCGCATGCTGTTCTCTAT & TTTTCATGAACAGCGCTCAC \\
\hline PHAVU_001G001300g & TGAAATGGCCAAGAAGGAAC & GGCGACGAGACCGTATATGT \\
\hline PHAVU_002G06700g & CTGATGAGCAGCAGCAGAAG & AAACGGGCATAAACAACAGC \\
\hline PHAVU_003G096400g & ACGACCATGGGTTGCTAGTC & AATGCTTCAGCTTCCTTCCA \\
\hline PHAVU_003G011600g & TAGTGATGGTGCAGGAGCTG & GATGCAAAGGCCTCATTGAT \\
\hline PHAVU_006G048600g & CAGGATGCTTGGGATGATCT & CAAGGGCCTTTCCTACTTCC \\
\hline PHAVU_008G057700g & TGCTTCACATGAATGGTGGT & CAACCCAAGTCTGCCACTTT \\
\hline PHAVU_008G272800g & TCCTTGTTGATGCCCACATA & CAAAGAAAAAGGGGGAGAGG \\
\hline PHAVU_011G176100g & CCCATGCACAGTGTACCAAG & ACCAATTAACCCCCAAGGAG \\
\hline PHAVU_011G17200g & GCTGATTTGGGATGCTCTTC & CGTTTCCCTTGTTGAGTGGT \\
\hline$\beta$-actin & GGAAAATCAGTCTCGGTTCAG & TCATACAGCAGCAAGCAC \\
\hline
\end{tabular}

TableS2. ANOVA table for the effect of PeBC1elicitor protein and temperature on the nymphal development time of green

peach aphids Myzuspersicae

\begin{tabular}{|c|c|c|c|c|c|c|c|c|c|c|c|c|c|c|c|c|}
\hline \multirow[b]{2}{*}{ SOV } & \multirow[b]{2}{*}{$\mathrm{df}$} & \multicolumn{3}{|c|}{ 1st Instar } & \multicolumn{3}{|c|}{ 2nd Instar } & \multicolumn{3}{|c|}{ 3rd Instar } & \multicolumn{3}{|c|}{ 4th Instar } & \multicolumn{3}{|c|}{ Overall } \\
\hline & & MS & $\begin{array}{c}\text { F- } \\
\text { Value }\end{array}$ & P-value & MS & $\begin{array}{c}\text { F- } \\
\text { Value }\end{array}$ & $\begin{array}{c}\text { P- } \\
\text { value }\end{array}$ & MS & F-Value & P-value & MS & $\begin{array}{c}\text { F- } \\
\text { Value }\end{array}$ & $P$-value & MS & F-Value & $P$-value \\
\hline Conc. & 3 & 4.06 & 2.84 & 0.04 & 7.09 & 6.17 & $<0.01$ & 6.94 & 6.91 & 0.003 & 7.12 & 6.26 & $<0.001$ & 15.91 & 12.71 & $<0.001$ \\
\hline Temp. & 2 & 74.53 & 52.27 & $<0.001$ & 104.36 & 90.89 & $\begin{array}{c}<0.00 \\
1\end{array}$ & $\begin{array}{c}123.2 \\
3\end{array}$ & 122.67 & $<0.001$ & 94.68 & 83.26 & $<0.001$ & 343.15 & 274.27 & $<0.001$ \\
\hline $\begin{array}{c}\text { Conc.x } \\
\text { Temp. }\end{array}$ & 6 & 0.52 & 0.37 & 0.89 & 1.25 & 1.09 & 0.38 & 3.00 & 2.99 & 0.01 & 1.69 & 1.49 & 0.19 & 7.02 & 5.61 & $<0.001$ \\
\hline Error & $\begin{array}{l}10 \\
8 \\
\end{array}$ & 1.43 & & & 1.15 & & & 1.01 & & & 1.14 & & & 1.25 & & \\
\hline Total & $\begin{array}{c}11 \\
9 \\
\end{array}$ & & & & & & & & & & & & & & & \\
\hline $\begin{array}{c}\text { Mean / } \\
\mathrm{CV}\end{array}$ & & 2.88 & 41.41 & & 3.27 & 2.80 & & 3.46 & 28.98 & & 3.23 & 35.18 & & 3.21 & 4.80 & \\
\hline
\end{tabular}


Basit A et al. (2020). Not Bot Horti Agrobo 48(2):705-715

TableS3. ANOVA table for the impact of PeBA1 elicitor protein and temperature on the fecundityof green peach aphid $M y z u s$ persicae

\begin{tabular}{|c|c|c|c|c|c|}
\hline SOV & DF & SS & MS & F-Value & P-value \\
\hline Conc. & 3 & 188.83 & 62.942 & 23.08 & $<0.001$ \\
\hline Temp. & 2 & 1402.52 & 701.258 & 225.72 & $<0.001$ \\
\hline Conc. $\times$ Temp. & 6 & 14.75 & 22.258 & 0.90 & 0.4967 \\
\hline Error & 108 & 2294.50 & 2.727 & & \\
\hline Total & 119 & 1900.59 & & & \\
\hline Grand Mean / CV & \multicolumn{7}{|l}{$15.058 / 10.97$} & & & \\
\hline
\end{tabular}

